\title{
Survival of cervical cancer patients and its prognostic factors at Cipto Mangunkusumo Hospital, Jakarta
}

\author{
Laila Nuranna, ${ }^{1}$ Rahma Prastasari, ${ }^{1}$ Bambang Sutrisna ${ }^{2}$ \\ ${ }^{1}$ Department of Obstetrics and Gynecology, Faculty of Medicine, Universitas Indonesia, Jakarta, Indonesia \\ ${ }^{2}$ Department of Epidemiology, Faculty of Public Health, Universitas Indonesia, Jakarta, Indonesia
}

\begin{abstract}
Abstrak
Latar belakang: Kanker serviks merupakan kanker kedua tersering pada perempuan Indonesia. Kesintasan hidup merupakan informasi yang penting bagi pasien dan institusi. Laporan kesintasan hidup pasien kanker serviks di RS Cipto Mangunkusumo dilakukan lebih dari 10 tahun yang lalu. Penelitian ini bertujuan mengetahui kesintasan hidup dan faktor-faktor prognostik pasien kanker serviks.
\end{abstract}

Metode: Penelitian ini memiliki desain kohort retrospektif yang meneliti pasien kanker serviks yang diterapi di RS Cipto Mangunkusumo tahun 2005-2006. Subjek diikuti sampai minimal 5 tahun. Analisis Kaplan-Meier dan regresi Cox dilakukan untuk menentukan probabilitas kesintasan dan menilai faktor-faktor prognostik.

Hasil: Sebanyak 447 pasien memenuhi kriteria penelitian. Proporsi terbanyak pada penelitian ini adalah pasien stadium III (41,6\%). Sebagian besar pasien memiliki jenis histopatologi karsinoma sel skuamosa (71,6\%). Pada penelitian ini didapatkan median kesintasan 63 bulan dengan kesintasan hidup 5 tahun sebanyak 52\%. Ukuran tumor tidak mempengaruhi kesintasan hidup. Stadium III dan IV memiliki kesintasan yang lebih rendah dibandingkan stadium I (HR 3,27 and 6,44). Diferensiasi buruk dan terapi tidak lengkap juga memiliki probabilitas kesintasan yang lebih rendah (HR 2,26 and 2,22). Jenis histopatologi lainnya (neuroendokrin) memiliki kesintasan yang lebih rendah (HR 2,85), walaupun pada uji multivariat tidak bermakna secara statistik.

Kesimpulan: Median kesintasan pasien kanker serviks pada penelitian ini sebesar 63 bulan. Hal ini menunjukkan perbaikan kesintasan dibandingkan studi pada tahun 1997. Faktor prognostik independen pada penelitian ini adalah stadium, diferensiasi tumor, dan kelengkapan terapi.

\begin{abstract}
Background: Cervical cancer is the second most common cancer among Indonesian women. Information concerning survival probability is very important for the patient and institution. Our last data about cervical cancer survival was studied for more than 10 years ago. This study aimed to know the latest cervical cancer survival and its prognostic factors.
\end{abstract}

Methods: This is a retrospective cohort study which enrolled cervical cancer patients treated at Cipto Mangunkusumo Hospital in 2005-2006. Subjects were followed-up for minimum of 5 years. Kaplan-Meier and Cox regression analysis was used to determine the survival probability and to assess prognostic factors.

Results: A total of 447 patients who met the study criteria were selected. Stage III was the largest proportion on the study $(41.6 \%)$. Most of the histopathology type was squamous cell carcinoma $(71.6 \%)$. This study revealed that median survival was 63 months with the overall 5 -years survival probability to be $52 \%$. Tumor size did not influence overall survival rate. Stage III and IV had lower survival probability (HR 3.27 and 6.44). Poor differentiation and uncompleted therapy also had lower survival probability (HR 2.26 and 2.22). Histopathology of others (neuroendocrine) had lower survival probability (HR 2.85). However, it was not statistically significant on multivariate analysis.

Conclusion: Median survival time for cervical cancer patients at Cipto Mangunkusumo Hospital was 63 months. There were improvement in the survival rate comparing from the study in 1997. In this study, the independent prognostic factors for survival were tumor staging, tumor differentiation, and completion of therapy.

Keywords: cervical cancer, prognostic factors, survival rate

pISSN: 0853-1773 • eISSN: 2252-8083 • http://dx.doi.org/10.13181/mji.v23i3.739 • Med J Indones. 2014;23:163-8 Correspondence author: Laila Nuranna, lailaril@gmail.com

Copyright@2014 Authors. This is an open access article distributed under the terms of the Creative Commons Attribution-NonCommercial-ShareAlike 4.0 International License (http://creativecommons.org/licenses/by-nc-sa/4.0/), which permits unrestricted non-commercial use, distribution, and reproduction in any medium, provided the original author and source are properly cited. 
Globally, cervical cancer is the third most common cancer in women and impacts 275,000 women death each year meaning a woman will die due to cervical cancer every two minutes. ${ }^{1}$ Cervical cancer is the second most common cancer among Indonesian women, after breast cancer. ${ }^{2}$ Thus, it is important for patient, family and cancer service institution to know the survival probability. Our last data about cervical cancer survival was studied over 10 years ago. ${ }^{3}$ During the time period, we observed many improvements in quality of cancer care in our institution such as cervical cancer screening, additional chemotherapy on advanced stages and insurance coverage (national insurance such as GAKIN/Jamkesmas). ${ }^{4}$ Therefore, this study was undertaken to know the latest cervical cancer survival at Cipto Mangunkusumo Hospital (CM Hospital) - which is the largest national referral hospital - and to assess the prognostic factors associated with the disease.

\section{METHODS}

This study was a retrospective cohort study. All patients diagnosed as cervical cancer in CM Hospital on 2005-2006 were included in this study. Data were acquired from oncology gynecology registry, surgery list, and radiotherapy registration database. Only patients with histopathology confirmed cervical cancer and who had available medical record were enrolled. Double primer and secondary cervical cancer were excluded. Patients who did not receive any therapy at CM hospital or whom already given therapy at other hospital were also excluded. This study has been approved by the Ethics Committee of Medical Faculty of Medicine, Universitas Indonesia (Reg. No 67/PT 02.FK/ETIK/2012).

We collected data including age, educational level, insurance coverage, place of residence, and phone number from the medical record. Clinical data included FIGO stage, tumor size, histopathology type, tumor differentiation, treatment modality, and completion of therapy. The recorded dates were time of diagnosis, last visit or last contact date, and time of death. All patients were followed up until minimal 5 years or the patients were dead or lost to follow up. Patients, who were lost to follow up, were contacted by phone or mail to know their current condition.

Every patient was staged based on FIGO (International Federation of Gynecology and Obstetrics) classification by gynecology oncologist. The stage was also evaluated using early and late stage. The early stage was equivalent with stage IA-IIA, whereas late stage was equivalent with stage IIB-IVB. Tumor size was measured clinically. Histopathology type and tumor differentiation obtained from histopathology examination result. Treatment modality was decided during staging. Patients who underwent all treatment modality were grouped as completed therapy group. Patient received chemo-radiation therapy was classified as completed therapy if all radiotherapy sequences (external and brachytherapy) and a minimum of three series chemotherapy were performed. Patients underwent surgery were classified as completed therapy if further management plan after surgery was done, based on the histopathology result.

Data were analyzed using STATA 10. Survival analysis was conducted by using Kaplan-Meier method. The survival curves were compared using Log-rank test. Suggested prognostic factors were analyzed to get hazard ratio using Cox-regression analysis and were continued by multivariate analysis.

\section{RESULTS}

The number of cervical cancer patients at CM Hospital during 2005-2006 was 955 patients. Among these patients, a total of 447 patients met the study criteria. Patients were followed up until the event (death) or survive for minimal five years or being lost to follow up. This study found 107 patients got the event or death $(23.9 \%), 73$ patients $(16.3 \%)$ were alive, and 267 patients $(59.7 \%)$ were lost to follow up.

Subject characteristics are shown in table 1 . Mean age of these patients was 47.5 years (SD \pm 8.6 ) ranging from 24 to 73 years. Most patients had education length for 12 years or less, lived in Jabodetabek (Jakarta, Bogor, Tangerang, Bekasi) and were supported by national insurance such as GAKIN or Jamkesmas.

Median survival time for cervical cancer was 63 months with overall survival rate at year 1,2 , and 5 were $84 \%, 70 \%$, and $52 \%$, respectively. Age, education, place of residence, and medication funding was not associated with overall survival from the Log-rank test.

Most patients came at late stage, with tumor diameter $>4 \mathrm{~cm}$, and had squamous cell carcinoma as shown on the Table 2. Half of these patients completed 
Table 1. Demographic characteristics and it's survival rate of the study subjects

\begin{tabular}{|c|c|c|c|c|c|}
\hline \multirow{2}{*}{ Variable } & \multirow{2}{*}{ Frequency $(\%)$} & \multicolumn{2}{|c|}{ Survival } & \multicolumn{2}{|c|}{ Log-rank } \\
\hline & & 5 years $(\%)$ & Median (months) & $\mathrm{X}^{2}$ & $\mathrm{p}$ \\
\hline Subject number & $447(100 \%)$ & & & & \\
\hline Age & & & & 1.14 & 0.567 \\
\hline$<30$ years & $3(0.7 \%)$ & 33 & 25 & & \\
\hline $31-49$ years & $296(66.2 \%)$ & 55 & $-*$ & & \\
\hline$>50$ years & $148(33.1 \%)$ & 48 & 60 & & \\
\hline Education length & & & & 0.06 & 0.972 \\
\hline$\leq 6$ years & $209(46.8 \%)$ & 47 & 47 & & \\
\hline $7-12$ years & $157(35.1 \%)$ & 52 & 63 & & \\
\hline$>12$ years & $26(5.8 \%)$ & 57 & $-*$ & & \\
\hline Not available data & $55(12.3 \%)$ & & & & \\
\hline Residence & & & & 0.56 & 0.756 \\
\hline Jabodetabek & $292(65.3 \%)$ & 55 & $-*$ & & \\
\hline Java (non Jabodetabek) & $95(21.33 \%)$ & 50 & 61 & & \\
\hline Outside Java & $60(13.4 \%)$ & 38 & 56 & & \\
\hline Medication cost sources & & & & 1.11 & 0.775 \\
\hline Gakin/Jamkes & $264(59.1 \%)$ & 47 & 51 & & \\
\hline SKTM & $59(13.2 \%)$ & 54 & $-*$ & & \\
\hline Askes & $76(17.0 \%)$ & 56 & $-*$ & & \\
\hline Private & $45(10.1 \%)$ & 60 & $-*$ & & \\
\hline Unknown & $3(0.7 \%)$ & & & & \\
\hline
\end{tabular}

*Median survival time is not available since less than $50 \%$ of the subjects experienced the event during the entire observation period

treatment protocol. Most of the patients received chemo-radiation as therapy protocol (73.8\%), followed by surgery combined chemo-radiation $(8.9 \%)$, radiotherapy only $(7.4 \%)$, surgery combined radiotherapy $(5.8 \%)$, and surgery only $(4.5 \%)$.

Survival rate in each FIGO stage is shown on figure 1. It is clearly shown that survival probability decreased with increased FIGO stage, proven by Log-rank test $(p<0.001)$. Stage IV had five-fold risk for mortality compared with stage I (Table 2). Incomplete therapy was also a significant factor showing worse survival probability compared with the complete one (Logrank test, $\mathrm{p}<0.001)$.

Kaplan-Meier survival curve of histopathology type showed different tendencies on survival probability (Log-rank test, $p=0.09$ ). Bivariate analysis revealed that lesser types of pathology (others) such as neuroendocrine, small cell carcinoma, glassy cell; had higher hazard ratio compared with squamous cell carcinoma $(\mathrm{HR}=2.85, \mathrm{p}=0.024)$. The survival curve on tumor differentiation has a trend to be different (Log-rank test, $p=0.07$ ). Eventhough not statistically significant, poor differentiation seemed to have higher hazard ratio compared with squamous cell carcinoma $(\mathrm{HR}=1.71, \mathrm{p}=0.071)$.

Multivariate analysis was conducted involving stage, tumorsize, histopathology type, tumor differentiation, and completion of therapy. Independent prognostic factors were FIGO stage, tumor differentiation, and completion of therapy (Table 3 ).

\section{DISCUSSION}

There were improvements in survival rate for cervical cancer patients in our institution over ten year period. Median survival time and overall five-years survival rate in 1997 were 13 months and 30\%, while in this study were 63 months and $52 \%$. Survival in each FIGO stage also show improvement compared from 1997. Median survival time for stages I, II, III, and IV in 1997 were 55, 39, 22 and 6 months. This improvement was not associated with earlier stage of the subject. Distribution for FIGO stage I, II, III, and IV from previous study were $14.55 \%, 31.92 \%, 46.48 \%$ and $7.04 \%$, with similar results in $2006 .{ }^{3}$ Therefore, improvement in the survival was considered caused by better services and treatment quality. 
Table 2. Association of clinical characteristics and survival

\begin{tabular}{|c|c|c|c|c|c|c|c|c|}
\hline \multirow[b]{2}{*}{ Variable } & \multirow[b]{2}{*}{ Frequency $(\%)$} & \multicolumn{2}{|c|}{ Survival } & \multicolumn{2}{|c|}{ Logrank } & \multicolumn{3}{|c|}{ Bivariate } \\
\hline & & $\begin{array}{c}5 \text { years } \\
(\%)\end{array}$ & $\begin{array}{l}\text { Median } \\
\text { (months) }\end{array}$ & $\mathrm{X}^{2}$ & $\mathrm{p}$ & HR & $\mathrm{p}$ & $95 \% \mathrm{CI}$ \\
\hline Subject number & $447(100 \%)$ & & & & & & & \\
\hline Stage (FIGO) & & & & 20.12 & 0.000 & & & \\
\hline Stage I & $84(18.8 \%)$ & 73 & $-*$ & & & 1 & & \\
\hline Stage II & $145(32.4 \%)$ & 52 & 63 & & & 1.49 & 0.170 & $0.84-2.64$ \\
\hline Stage III & $186(41.6 \%)$ & 36 & 36 & & & 2.57 & 0.000 & $1.51-4.36$ \\
\hline Stage IV & $32(7.2 \%)$ & 0 & 11 & & & 5.16 & 0.001 & $1.89-14.07$ \\
\hline Stage & & & & 9.67 & 0.001 & & & \\
\hline Early (IB - IIA) & $137(30.6 \%)$ & 67 & $-*$ & & & 1 & & \\
\hline Late (IIB - IVB) & $310(69.4 \%)$ & 41 & 44 & & & 1.94 & 0.002 & $1.27-2.96$ \\
\hline Tumor diameter & & & & 3.27 & 0.070 & & & \\
\hline$\leq 4 \mathrm{~cm}$ & $113(25.3 \%)$ & 56 & $-*$ & & & 1 & & \\
\hline$>4 \mathrm{~cm}$ & $334(74.7 \%)$ & 47 & 57 & & & 1.63 & 0.567 & $0.57-2.76$ \\
\hline Histopathology type & & & & 6.36 & 0.090 & & & \\
\hline Squamous cell Ca & $320(71.6 \%)$ & 51 & 63 & & & 1 & & \\
\hline Adenocarcinoma & $53(11.9 \%)$ & 59 & $-*$ & & & 0.84 & 0.55 & $0.47-1.48$ \\
\hline Adenosquamous & $58(13.6 \%)$ & 50 & $-*$ & & & 0.96 & 1 & $0.53-1.74$ \\
\hline Others & $16(3.6 \%)$ & 30 & 18 & & & 2.85 & 0.904 & $1.14-7.09$ \\
\hline Tumor differentiation & & & & 5.29 & 0.071 & & & \\
\hline Well & $92(20.6 \%)$ & 50 & $-*$ & & & 1 & & \\
\hline Moderate & $247(55.2 \%)$ & 56 & $-*$ & & & 0.96 & 0.868 & $0.59-1.56$ \\
\hline Poor & $74(16.6 \%)$ & 37 & 39 & & & 1.71 & 0.078 & $0.94-3.12$ \\
\hline No available data & $34(7.6 \%)$ & & & & & & & \\
\hline Therapy completeness & & & & 14.29 & 0.000 & & & \\
\hline Complete & $228(51.0 \%)$ & 60 & $-*$ & & & 1 & & \\
\hline Incomplete & 219 & 37 & 32 & & & 1.74 & 0.697 & $0.80-3.82$ \\
\hline
\end{tabular}

*Median survival time is not available since less than $50 \%$ of the subjects experienced the event during the entire observation period

Our results in this study were still below the FIGO report, which the 5-years survival rate probability on stage I was $75.7 \%-97.5 \%$, stage II $65.8 \%-73.4 \%$, stage III $39.7-41.5 \%$ and stage IV $9.3-22 \%$. This differences presumably due to the lower prevalence of early stage (30.6\%) in this study than FIGO report $(53.45 \%)^{5}$

Based on multivariate analysis, there were several factors independently associated with decreased survival such as late FIGO stages, poor tumor differentiation, and incomplete therapy. Consistent with other studies, increased stage will upscale hazard ratio in cervical cancer patients. In this study, Hazard Ratio (HR) for stage III and IV compared to stage I were 3.27 (95\% CI 1.789-5.994) and 6.44 (95\% CI 2.064-10.092). These results were similar with the result at CM Hospital in 1997.,6,7

Poor differentiation showed worse survival in this study and was proven as independent factor by multivariate analysis. This result was consistent with other studies. ${ }^{8,9}$ Incomplete therapy, consistent with previous study at CM Hospital, also showed poorer prognosis. Patients who received incomplete therapy were two times more likely to die than those whom 
Table 3. Multivariate analysis of prognostic factors for cervical cancer survival

\begin{tabular}{|c|c|c|c|c|c|}
\hline Factor & $\begin{array}{c}\text { Adjusted hazard } \\
\text { ratio }\end{array}$ & SE & Z & $\mathrm{P}$ & $95 \% \mathrm{CI}$ \\
\hline \multicolumn{6}{|l|}{ Stage $*$} \\
\hline Stage I & 1 & & & & \\
\hline Stage II & 1.72 & 0.543 & 1.72 & 0.086 & $0.926-3.194$ \\
\hline Stage III & 3.27 & 1.010 & 3.85 & 0.000 & $1.789-5.994$ \\
\hline Stage IV & 6.44 & 3.738 & 3.21 & 0.001 & $2.064-10.092$ \\
\hline \multicolumn{6}{|l|}{ Tumor differentiation* } \\
\hline Well & 1 & & & & \\
\hline Moderate & 1.10 & 0.284 & 0.38 & 0.702 & $0.666-1.829$ \\
\hline Poor & 2.26 & 0.741 & 2.48 & 0.013 & $1.185-4.296$ \\
\hline \multicolumn{6}{|l|}{ Histopathology type } \\
\hline Squamous cell carcinoma & 1 & & & & \\
\hline Adenocarcinoma & 1.27 & 0.399 & 0.75 & 0.452 & $0.683-2.349$ \\
\hline Adenosquamous & 1.24 & 0.427 & 0.63 & 0.527 & $0.634-2.436$ \\
\hline Others & 2.62 & 2.684 & 0.94 & 0.349 & $0.350-19.536$ \\
\hline \multicolumn{6}{|l|}{ Completion of therapy * } \\
\hline Complete & 1 & & & & \\
\hline Incomplete & 2.22 & 0.463 & 3.84 & 0.000 & $1.478-3.343$ \\
\hline
\end{tabular}

* The result was statistically significant
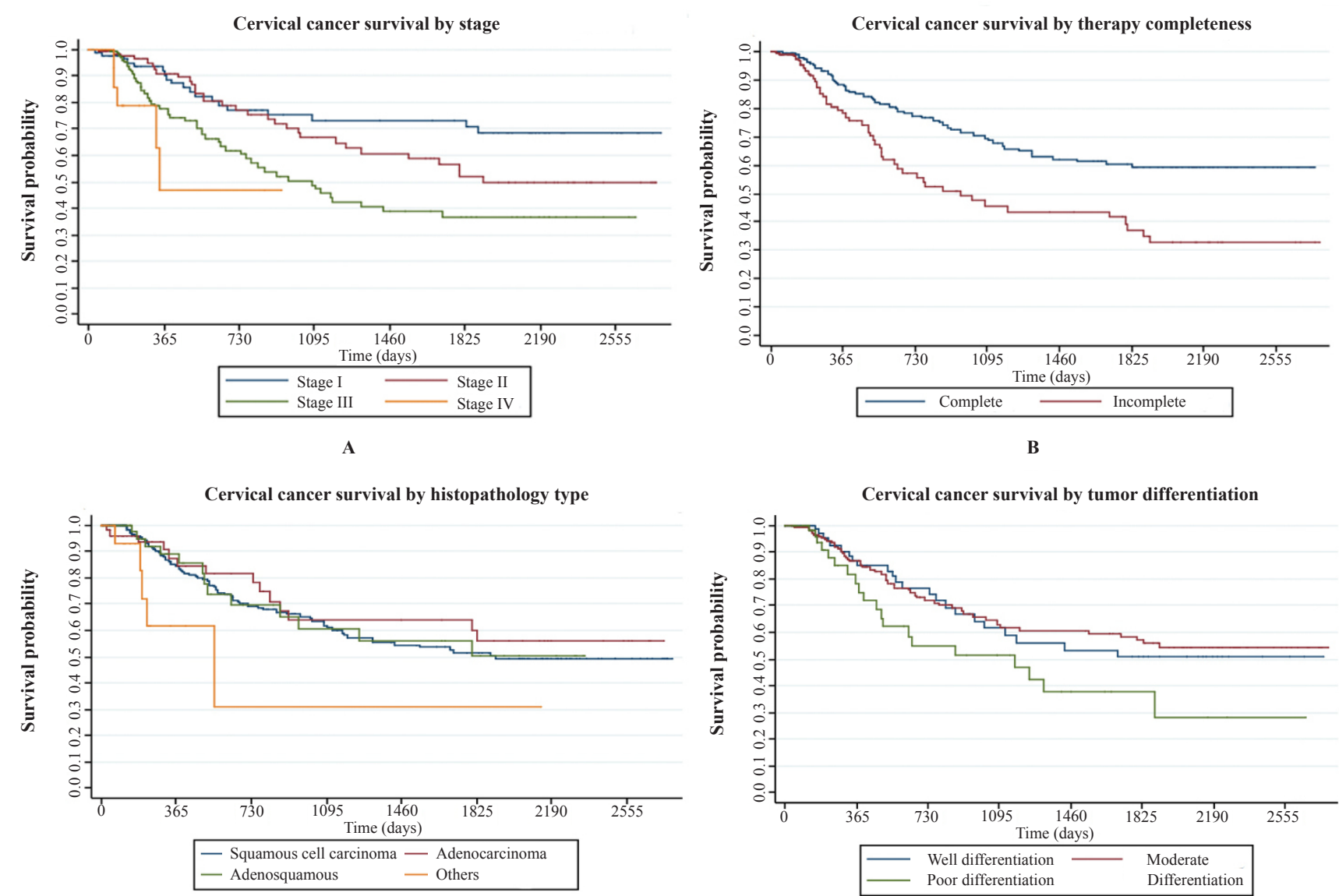

D

Figure 1. Kaplan-Meier curve of cervical cancer survival by (a) Stage, (b) Therapy completeness, (c) Histopathology type, and (d) Tumor differentiation 
completed the treatment (HR: $2.17,95 \%$ CI 1.45 3.24). Although the number of patients completing therapy decreased $(82.2 \%$ to $70.47 \%)$, overall survival probability was increased, either in completed or incomplete group. As mentioned before, this might be partially explained due to improved services quality. ${ }^{3}$

In this study, age, education length, and medication funding did not appear to be significant factors for survival rate. Some studies abroad reported that these variables were associated with cervical cancer survival. ${ }^{8,10}$

Histopathology types were not associated with survival in this study. Squamous cell carcinoma, adenocarcinoma, and adenosquamous carcinoma had similar survival rate. Data from several studies showed controversial result concerning association between histopathology types of cervical cancer with survival. Adenocarcinoma was reported to have poorer prognosis than squamous cell carcinoma, ${ }^{5,11}$ but other studies reported no differences. ${ }^{12,13}$ FIGO reported other types of histopathology have poor prognosis, while in this study there was also a tendency towards poorer prognosis (HR 2.62, 95\% CI 1.14 - 7.09). However, this was not statistically significant on multivariate analysis (HR 2.2, 95\% CI $0.350-19.536$ ). This finding might be due to small sample size. ${ }^{5}$

In conclusion, median survival time of cervical cancer patients was 63 months. Overall five years survival rate for cervical cancer patients at Cipto Mangunkusumo Hospital was 52\%. The five years survival rate probability for stage I, II, III, and IV were $73 \%, 52 \%, 36 \%$, and undetected, consecutively. There were improvements in overall survival, compared with previous data in 1997. Independent prognostic factors in this study were stage, tumor differentiation, and completion of therapy.

\section{Conflict of interest}

All authors have nothing to disclose.

\section{REFERENCES}

1. American Cancer Society. Global cancer facts and figures. 2nd ed. Atlanta: American Cancer Society; 2011.

2. Persatuan Dokter Spesialis Patologi Indonesia. Kanker di Indonesia tahun 2008: data histopatologik. Jakarta: Yayasan Kanker Indonesia; 2012. Indonesian.

3. Sirait AM, Ariawan I, Aziz F. Ketahanan hidup penderita kanker serviks di Rumah Sakit Dr Cipto Mangunkusumo Jakarta. Maj Obstet Ginekol Indones. 1997;21(3):183-90. Indonesian.

4. Eifel PJ. Concurrent chemotherapy and radiation: a major advance for women with cervical cancer. JCO. 1999;17(5):1334-5.

5. Quinn MA, Benedet JL, Odicino F, Maisonneuve P, Beller U, Creasman WT, et al. Carcinoma of the cervix uteri. FIGO 26th Annual Report on the Results of Treatment in Gynecological Cancer. Int J Gynaecol Obstet. 2006;95 Suppl 1:S43-103.

6. Atahan IL, Onal C, Ozyar E, Yiliz F, Selek U, Kose F. Long-term outcome and prognostic factors in patients with cervical carcinoma: a retrospective study. Int J Gynaecol Obstet. 2007;17(4):833-42.

7. Seamon LG, Tarrant RL, Fleming ST, Vanderpool RC, Pachtman S, Podzielinski I, et al. Cervical cancer survival for patients referred to a tertiary care center in Kentucky. Gynecol Oncol. 2011;123(3):565-70.

8. Brookfield KF, Cheung MC, Lucci J, Fleming LE, Koniaris LG. Disparities in survival among women with invasive cervical cancer: a problem of access to care. Cancer. 2009;115(1):166-78.

9. Swangvaree SS, Adulbhan A, Talacheep S, Thepsuwan D, Tabtimsri K, Boonpen P, et al. Cervical cancer survival at the National Cancer Institute, Thailand. Thai Cancer Journal. 2010;30(3):87-93.

10. Eggleston KS, Coker AL, Williams M, Tortolero-Luna G, Martin JB, Tortolero SR. Cervical cancer survival by socioeconomic status, race/ethnicity, and place of residence in Texas, 1995-2001. J Womens Health (Larchmt). 2006;15(8):941-51.

11. Galic V, Herzog TJ, Lewin SN, Neugut AI, Burke WM, $\mathrm{Lu}$ YS, et al. Prognostic significance of adenocarcinoma histology in women with cervical cancer. Gynecol Oncol. 2012;125(2):287-91.

12. Brewster WR, DiSaia PJ, Monk BJ, Ziogas A, Yamada $\mathrm{SD}$, Anton-Culver H. Young age as a prognostic factor in cervical cancer: results of a population-based study. Am J Obstet Gynecol. 1999;180(6 Pt 1):1464-7.

13. Katanyoo K, Sanguanrungsirikul S, Manusirivithaya S. Comparison of treatment outcomes between squamous cell carcinoma and adenocarcinoma in locally advanced cervical cancer. Gynecol Oncol. 2012;125(2):292-6. 